\title{
Andrey T. Junger as a Representative of the Military Administration of the Romanov Dynasty in Dagestan
}

\author{
Nikolay D. Chekulaev \\ Institute of History, Archeology and Ethnography of Dagestan Federal Research Center of \\ the Russian Academy of Sciences. Makhachkala, Russia. Email: koctin1974[at]mail.ru
}

\begin{abstract}
Based on the archival documents and the works of Russian kavkazologists, the article attempts to study the strategy of Russian national policy in the Caucasus. The purpose of the study is to show the place and role of one of the leaders of the Russian military administration in Dagestan Commandant A.T. Junger as well as to identify his rights and powers as the head of the Russian military administration in Derbent. The research material is based on the archival documents of the $18^{\text {th }}$ century (RGADA, RGVIA, RGAVMF) which are stored in the Russian archives and most of which are introduced into the scientific circulation for the first time. Furthermore, the achievements of Russian historians on the problem under study are widely used. The basic principles of scientific objectivity and historicism are used, involving the study of historical facts and events in the specific historical conditions with a focus on the development and interdependence of historical events as well as multivariation of the historical process. Leaving Derbent, Emperor Peter I entrusted all the management of affairs to the appointed commandant. According to his plan, the fullness of military, civil, and political power was concentrated in the hands of the commandant of Derbent, both in the fortress itself and in its district many miles away from it. The duties of the commandant also included the management of the garrison located in the fortress, supervision of order, tranquility in the fortress and outside it, and the protection of the city from the enemy. Its jurisdiction also included financial, economic, administrative and political functions. Using the identified historical sources, it was revealed that the commandant A.T. Junger, entering into negotiations with local feudal rulers, personified a representative of the government of the Russian Empire.
\end{abstract}

Keywords

Russian Empire; Peter the Great; Caucasian Politics; Dagestan; Derbent Garnison; Andrey T. Junger; Commandant; Powers of Authority

This work is licensed under a Creative Commons "Attribution" 4.0 International License 


\section{Андрей Томасович Юнгер как представитель военной администрации династии Романовых в Дагестане}

\section{Чекулаев Николай Дмитриевич}

Институт Истории, археологии и этнографии Дагестанского федерального исследовательского центра РАН. Махачкала, Россия. Email: koctin1974[at]mail.ru

\section{Аннотация}

В данной статье на материале архивных документов и историографических источников рассматривается стратегия национальной политики России на Кавказе. Показывается место и роль в её осуществлении одного из руководителей российской военной администрации в Дагестане - коменданта А.Т. Юнгера. Очерчиваются права и полномочия А.Т. Юнгера как главы военной администрации России в Дербенте. Большинство документов федеральных архивов РГАДА, РГВИА, РГАВМФ (XVIII в.) впервые вводятся в научный оборот. Соблюдаются принципы научности, объективности и историзма, предполагающие изучение фактов и событий в конкретных условиях, рассмотрение их в причинно-следственной связи, развития и взаимозависимости событий. Завершая Персидский поход, Петр I поручил управление Дербентом и Дербентской провинцией назначенному коменданту. По замыслу императора, в руках коменданта Дербента сосредотачивалась вся полнота военной, гражданской, политической власти, как в самой крепости, так и в её округе. В обязанности коменданта вменялись управление гарнизоном, наблюдение за порядком, охрана города. Его юрисдикция включала финансовые, хозяйственно-административные и политические вопросы. Комендант А.Т. Юнгер, вступая в переговоры с местными феодальными правителями, олицетворял собой представителя правительства Российской империи.

\section{Ключевые слова}

Российская империя; Петр Великий; кавказская политика; Дагестан; Дербентский гарнизон; А.Т. Юнгер; комендант; полномочия

Это произведение доступно по лицензии Creative Commons “Attribution” («Атрибуция») 4.0 Всемирная 


\section{Введение}

Данная проблема мало исследована в трудах отечественных кавказоведов. На наш взгляд, в исторической литературе не дана достойная оценка роли комендантов российских гарнизонов в осуществлении кавказской политики России в Дагестане в 1722-1735 гг., да и в последующее время. Основное внимание уделяется изучению противоборства Турции, Ирану за господство над Северным Кавказом. В отечественном кавказоведении не уделено никакого внимания тем, кто занимался осуществлением на практике кавказской политики Российской империи.

Отечественные кавказоведы в своих трудах не только не рассматривают деятельность комендантов Низового корпуса, но и не сообщают о том, кто был комендантом той или иной крепости на Северном Кавказе. Лишь П.Г. Бутков в своем труде дает список комендантов Терской крепости и крепости Святого Креста. А вот о российских комендантах Дербента первой трети XVIII в. историки умалчивают, лишь упоминают об одном из них - А.Т. Юнгере.

Российские кавказоведы П.Г. Бутков и Е.И. Козубский сообщают, что назначенный императором Петром I полковник А.Т. Юнгер являлся комендантом Дербента вплоть до возвращения города Ирану, т.е. до 1735 г. Но архивные документы опровергают подобные сведения российских историков и доказывают, что полковник А.Т. Юнгер был комендантом Дербента до весны 1731 г.

\section{Методы и материалы}

Мы осуществляли исследование на материалах документов российских архивов (ЦГА РД, РГАДА, РГВИА и РГВМФ), большинство из которых впервые вводятся в научный оборот. Они позволяют детально рассмотреть проблему функционирования российской военной администрации, ее взаимоотношения с местной дагестанской элитой. Помимо этого, выявленные архивные документы освещают деятельность императорской администрации России в Дербенте по освоению и использованию природных ресурсов западного побережья Каспийского побережья - создание и функционирование так называемого «Дворцового хозяйства Е.И.В.» в Дербенте.

\section{Анализ}

Андрей Томасович Юнгер происходил из иностранцев, которые приехали в Россию в правление царя Михаила Федоровича Романова. Вот как он писал о своем происхождении 20 марта 1720 г.:

«В прошедшем 1636 году июня 12 дня выехал дед мой Эрчвалт Юнгер... в Москву порутчиком из шкотцкой земли» (Бабич, 2005, с. 39). 
Эрчвалт (в прочих документах называется также Валтасаром, Бальцартом, Анцибальдом и т.д.) в начале 40-х гг. XVII в. упоминался капитаном, позднее произведен в ротмистры. Военную карьеру закончил в чине подполковника (там же).

Его сын Томас (Фома), как и отец, стал военным. В 1670 г. произведен в капитаны, в 1688 г. назначен главой рейтарского полка, участвовал в походе князя В.В. Голицына в Крым. В звании полковника одного из тамбовских полков принял участие в Азовских походах царя Петра (Бобровский, 1892, с. 78). В Азовских походах 1695-1696 гг. участвовали и его сыновья - Алферий и Андрей (Бабич, 2005, с. 39). Свою военную службу отец Андрея Юнгера проходил во Владимирском пехотном полку, который был сформирован 25 июня 1700 г. в селе Преображенском генералом Вейде и назван в честь Томаса Юнгера - Юнгоровым: «пехотного Юнгора Владимирский полк» (Владимирский пехотный полк, 1994, с. 109).

Андрей Томасович Юнгер поступил на военную службу в 1694 г. и долгое время служил вместе с родным братом Алферием. Они участвовали в неудачных для России сражениях Северной войны под г. Нарвой в 1700 г.; походе 1701 г. под г. Ригу (Андрей Томасович состоял уже в чине поручика, полк понес потери более 300 человек); взятии Нотебурга в 1702 г. (Бабич, 2005, с. 40).

Отец братьев, полковник Томас Юнгер, был назначен комендантом крепости Нотербург, которую переименовали в Шлиссельбург. С этого момента братья стали воевать по отдельности. Алферий Юнгер в составе Владимирского полка активно участвовал в сражениях Северной войны (походы под Выборг, Ревель и Ригу и т.д.) и в 1724 г., после её завершения, был переведен в Новгородский пехотный полк; на тот момент он имел чин полковника. Их отец служил комендантом до 1703 г., а потом вышел в отставку и переехал в Москву; о дальнейшей его судьбе источники умалчивают (Бабич, 2005, с. 40-41).

Андрей Юнгер в составе Рязанского пехотного полка принимал участие во взятии Ниеншанца, Митавы, в сражениях у Опршни и в Полтавской битве (Гистория Свейской войны, 2004, с. 39). В 1715 г. его по указу Петра I произвели в полковники. По распоряжению императора 27 ноября А.Т. Юнгера определили в часть Рязанского пехотного полка, включенную в русский экспедиционный корпус, который должен был совершить поход на Кавказ (Шеленговский, 1909, с. 140).

В обязанности Юнгера входило заниматься непосредственной подготовкой войск к походу на юг: обеспечивать оружием, обмундированием, транспортом. Из Ярославля А.Т. Юнгер сообщал в Военную коллегию, что он встречает упорное сопротивление со стороны местных властей, не желающих предоставить по его требованию войскам - лесные припасы, транспорт, строительный инструмент и рабочую силу (Бабич, 2005, с. 39). 
Летом 1722 г. Петр I во главе многотысячного войска отправился в поход на Кавказ. Российские войска состояли из регулярных полков, казачества и калмыков. В состав регулярных полков были включены 20 пехотных батальонов, в число которых входило подразделение Рязанского пехотного полка, в составе коего и служил А.Т. Юнгер, (РГВИА, ф. 20, оп. 1/47, д. 10, л. 88 об.), семь драгунских полков, казачьих войск и калмыков.

В результате действий императорских войск во время Персидского похода были заняты наиболее важные пункты: Эндирей, Тарки, Дербент. Но возникшие неблагоприятные события - гибель судов с продовольствием, падеж лошадей, большое количество больных из-за непривычного климата и проч. - вынудили Петра Великого прекратить свой поход и поворачивать назад, в Россию.

Уходя из Дагестана, император Петр Великий расквартировал в стратегически важных пунктах российские гарнизоны: в Дербенте, Рубасе, Буйнаке, Тарках и дано указание о строительстве крепости Святого Креста. Осенью 1722 г. Петр I во главе русской армии покинул Дагестан и возвратился в Астрахань (Маркова, 1966, с. 28-29).

На следующий день, 30 августа 1722 г., после назначения А.Т. Юнгера комендантом Дербента граф генерал-адмирал Ф.А. Апраксин дает ему подробную инструкцию по управлению городом. Нами в ходе работы в военно-морском архиве обнаружен документ, фиксирующий данное событие; он впервые вводится в научный оборот. Ценность данного документа состоит в том, что в нем сформулированы права и обязанности российского коменданта. Мы посчитали необходимым процитировать его практически полностью.

«Господину полковнику Юнгору быть в городе Дербене камендантом и с ним полуполковнику фон Лукею з двумя баталионы салдат, в полном комплекте, ис семью десять двумя человеки гранодеров и с полным числом афицеров, и управлять по ниже писанным пунктам.

1. Принять у полковника фон Страла верхнюю крепость со всею здешнею артиллериею, и пороховою казною, и что надлежит у здешних пушак починки, починить своими людьми, и поставить по местам, и содержать во своем ведении, так как военной устав повелевает.

2. Со управителем дербенским наипом иметь согласие, и поступать ласково, и в среднем городе ево команды не отнимать, и по воротам оной крепости караулам быть от него, или как с общаго согласия заблогоразсудите.

3. Нижней город ведать вам же и ворота запереть боковые на поле, но сие чинить с согласия с наипом. И никово Персию не пущать и разве когда наип будет говорить для отправления какова купечества отправлять какое судно тогда отпирать и караул иметь малой, только для ведомости.

4. Ежели будут происходить между здешних обывателей и салдат какие ссоры и будет челобитье, розыскивать праведно, буде побьет челом персиянин, то сказать чрез посылку наипу, чтоб для розыску приехал, буде же сам при том 
быть не похочет, то б прислал своего юзбашу. А вам от себя посылать афицера и розыскивать верно и ни в какие не праведныя обиды не допущать. А ежели салдат побьет челом на дербенского жителя, то делать против вышеписанного ж, а буде учинитца ссора между афицерами, то разсуждать самим купно с наипом. А буде подлых людей, то определить афицера, а к наипу послать, чтоб от себя афицера ж определил, и так все ссоры купно с ними вышеписанным порядком судить, наказания чинить каждому народу по их правам.

5. В верхнюю крепость кроме наипа и присланных от него жителей здешних кроме тех, которыя там живут домами без своего позволения никого не пущать, и ворота в верхней крепости и нижнего города также и которыя есть на поля держать под своим караулом и без дела не отворять, только калитку иметь отперту у тех ворот, которые в нижний город.

6. Провианту принимать немедленно, и положить в нижнюю крепость для скорости и что будет писать к нам, и поручить полковому камисару и на каманду свою раздавать по регламенту, и со временем перевесть в верхнюю крепость, також что впредь прислано будет и что выгружено на речке Кюлемет перевозить в верхнюю крепость, все как правиант так алтилерию, амуницию, и протчие вещи иметь в верхней крепости.

7. Жалованья денежного оставляетца вам на целой год от сентября с камисаром.

8. Для содержания здешней крепости принять артилерию от маеора Габора пороху пушечного двести пудов, мушкетного сто пуд, фитилю пятьдесят пуд, такоже и протчего, что вам надобно требовать от него же Гарбора, а от нас указ к нему, чтоб по требованию вашему отпускать указ послан

9. Християне, которыя от дербенских жителей будут к нему полковнику приходить, тех имена велеть записывать, а их по прежнему отдавать их хозяевам, и велеть их держать у себя впредь до указу, токмо того смотрить накрепко, чтоб христиан не приводили в магометанской или в персицкой закон, и сказать наипу, чтобы он велел во всем городе публиковать, дабы все дербенские жители подали ему наипу ведение, сколько у кого христиан есть, а он бы наип о том ведомость дал ему полковнику (РГАВМФ, ф. 233, оп. 1, д. 216, л. 198-201).

Документ позволяет сделать следующие выводы. Российское правительство предоставляло коменданту Дербента полномочия гражданской и военной власти на подконтрольной территории. При этом регламентировалось, как комендант должен поступать в той или иной ситуации. Немаловажный аспект правительственного рескрипта состоял в том, что коменданту Юнгеру, главе императорской военной администрации, давались распоряжения, как относиться к имеющейся в Дербенте местной элите, при этом требовалось не только сохранить полностью власть наиба Имам Кули-бека, но и при принятии многих своих приказов учитывать его мнение и отношение к той или иной проблеме.

Дальнейшая часть нашей публикации будет посвящена вопросу, как комендант А.Т. Юнгер на практике реализовывал предоставленные правительством Российской империи права и полномочия по управлению Дербентом.

Правящие круги Турции не хотели признавать присоединение Прикаспия в состав Российской империи. С этой целью турки непрерывно подстрекали 
дагестанских владетелей на антироссийские акции, главной целью которых было изгнание российских войск из Дагестана. Коменданту А.Т. Юнгеру неоднократно приходилось организовывать отражение неприятельских нападений на Дербент и близлежащие укрепления.

В донесении от 20 сентября 1722 г. комендант Дербента А.Т. Юнгер уведомлял кабинет-секретаря А.В. Макарова о взятии 14 сентября объединенным войском уцмия Кайтага, Сурхая и правителя Утамыша российского укрепления, находившегося между Дербентом и Тарками, а также о нападении горских войск на транжемент на реке Дарвагчай (РГАДА, ф. 9, оп. 4, д. 61, л. 863 и об.).

15 октября 1722 г. комендант А.Т. Юнгер писал графу Ф.М. Апраксину о том, что из-за антироссийских действий уцмия Кайтага и Хаджи-Давуда Мюшкюрского в Дербенте ощущается недостаток провианта, а сами неприятели находятся неподалеку от транжементов на Милюкенте, укрепления осаждены врагами (РГАВМФ, ф. 233, оп. 1, д. 211, л. 143 и об.). 23-25 октября по сведениям от коменданта А.Т. Юнгера происходили серьезные бои с войсками Давуд-бека и уцмия у стен Дербента. Подобные события происходили 2 и 3 ноября (РГАВМФ, ф. 233, оп. 1, д. 211, л. 152-154 и об.). А 8 ноября 1722 г. комендант А.Т. Юнгер уведомлял графа Ф.М. Апраксина о нападениях неприятелей уже на сам Дербент (РГАВМФ, ф. 233, оп. 1, д. 211, л. 144 и об.). 13 ноября 1722 г. А.Т. Юнгер сообщал графу Ф.М. Апраксину, что в ответ на непрерывные нападения на Дербент войска Хаджи-Давуда дербентцы численностью в 400 человек вышли из города и сумели нанести поражение неприятелю, возвратиться в город с большим числом добычи (РГАВМФ, ф. 233, оп. 1, д. 211, л. 147 и об.). 17 ноября случилось новое нападение войск уцмия Кайтага на Дербент. 31 декабря уцмий уже вместе с Дауд-беком снова атаковал Дербент (РГАДА, ф. 9, оп. 4, д. 63, л. 624 и об.; д. 61. 867-868).

Несмотря на непростую обстановку вокруг Дербента, сложившуюся с уходом основных сил императора, российское командование в лице коменданта А.Т. Юнгера старалось не обострять отношения с дагестанскими владетелями и их подданными. Местные владетели писали коменданту о дружбе, называя его «Андрей-бек», «благородный господин полковник / комендант и боярин дербентский», желая «в совете и дружбе жить, старова не надо поминать», уведомляли о поражении турецких войск. Из донесения А.Т. Юнгера кабинет-секретарю А.В. Макарову от 12 сентября 1725 г. видно, что ему удалось наладить отношения с уцмием Кайтага, который признал вину и согласился возместить ущерб за нападение его людей на Дербент 24 августа 1725 г. В своем письме коменданту уцмий заверял, чтобы «впредь противностей и всякой вражды между нами никакой бы не было и чтоб всегда были в приятстве». Комендант пытался также урегулировать конфликт между российской администрацией и шамхалом Адиль-Гиреем, который из союзников России превратился в ее врага (Магарамов \& Магомедов, 2021, с. 134). 
Доброжелательное отношение военной администрации во главе с А.Т. Юнгером к местному населению способствовало тому, что как родственники самого наиба Дербента, так и простые горожане неоднократно передавали русским властям сведения об антироссийских замыслах ряда дагестанских владетелей. Так 28 октября 1722 г. дядя наиба Мамета Юсуп-бека сообщил о действиях Давуд-бека, а 30 октября и 1 ноября дербентцы донесли о намерении Дауд-бека в союзе с андреевским владельцем Чупаном и табасаранским владетелем Максимом напасть на Дербент (РГАВМФ, ф. 233, оп. 1, д. 211, л. 152-154 и об.).

А.Т. Юнгер умело сочетая свои военные и управленческие способности помогли ему в управлении Дербентом и российским гарнизоном в условиях обострения обстановки связанные с ослаблением Ирана и усиления агрессивной политики Турции на Кавказе.

Выявленные из российских архивов документы свидетельствуют, что комендант Дербента А.Т. Юнгер регулярно отправлял в различные правительственные инстанции в Астрахань и в Санкт-Петербург своему вышестоящему начальству по Низовому корпусу (генералу М.А. Матюшкину) все полученные из различных источников сведения о происходящих событиях в самом Дербенте, его окрестностях, в Дагестане в целом. Большое внимание при этом уделялось информации о замыслах и действиях наиболее влиятельных дагестанских лиц - уцмии Кайтага, Сурхай-хана, Дауд-бека, табасаранских и кумыкских владетелей.

Так, 19 декабря 1722 г. кабинет-секретарь А.В. Макаров получил сообщение, в котором центральное место занимали данные о планах уцмия Кайтага и Давуд-бека (РГАДА, ф. 9, оп. 4, д. 61, л. 867-868). В январе 1723 г. главнокомандующему Низовым корпусом генералу М.А. Матюшкину пришло письмо о том, что казикумухский хан направил послание к наипу Дербента: стало известно, что уцмий и Сурхай не только поссорились с Давуд-беком, но и решили выгнать предводителя из его владений. Дербентские жители совершили ответное нападение на владения уцмия Кайтага, причинив значительный урон (РГАДА, ф. 9, оп. 4, д. 63, л. 624 и об.; л. 624 и об.).

В мае 1723 г. комендант А.Т. Юнгер в своем письме уведомил губернатора Астрахани Волынскому А.П., что кумыкский правитель Султан - Махмуд донес информацию, согласно которой «де намерен из Крыма Бахти-Гирей солтан с своими, совокупясь с уцмием и Дауд-беком и прочими горскими басюрманскими народами идти на крепость Святого Креста» (Сотавов, 2002, c. 103-104, 116).

В 1725 г. А.Т. Юнгер доносил в Петербург сведения о антироссийских замыслах дагестанских владельцев: якобы «посол шамхала Малабек» побывал у шаха, передал обращение Адиль-Гирея и уцмия просить «в их винах», ожидается нападение иранцев $\mathrm{c}$ шамхальскими и кайтагскими войсками на бакинский и дербентский уезды» (ЦГАРД, ф. 1, оп. 1, д. 2а, л. 3-4). 
В апреле 1725 г. комендант А.Т. Юнгер доложил генералу М.А. Матюшкину, что он из нескольких источников получил сведения о антироссийских намерениях шамхала Тарковского Адиль-Гирея (Курукин, 2010, с. 141-142). А 24 апреля комендант получил донесение из Терского гарнизона - сведения о взятии в плен Тарковским шамхалом русских купцов (ЦГАРД, ф. 18, оп. 1, д. 5, л.1 и об.). 15 мая 1725 г. А.Т. Юнгер сообщал кабинет-секретарю А.В. Макарову об антироссийских действиях шамхала Адиль-Гирея, в частности, об аресте находившихся в Тарках русских подданных (купцов, военных чинов - Н.Ч.) (РГАДА, ф. 9, оп. 4 , д. 74 , л. 833-834).

11 июля 1725 г. комендант А.Т. Юнгер писал кабинет-секретарю А.В. Макарову о походе из Дербента воинской команды во главе с подполковником фон Лукеем в табасаранское владение против его владельца. Основной целью похода было разорение деревни Марага в Табасаране (РГАДА, ф. 9, оп. 4, д. 74, л. 841-843).

Осенью 1725 г. комендант А.Т. Юнгер сообщил правительству о получении им в сентябре письма от уцмия Кайтага на его имя и имя наиба Дербента, в котором тот выражал готовность установить добрососедские отношения с российскими властями в Дагестане - с последующим намерением вступить в подданство Российской империи (РГАДА, ф. 9, оп. 4, д. 74, л. 847). 12 сентября комендант А.Т. Юнгер докладывал кабинет-секретарю А.В. Макарову о намерении уцмия Кайтага признать свою вину перед Российской империей и компенсировать ущерб, причиненный своими нападениями на Дербент (РГАДА, ф. 9, оп. 4, д. 74, л. 845-846 об.).

3 июня 1726 г. из донесения коменданта А.Т. Юнгера стало известно, что правитель Кайтага, его сыновья, правитель Утамыша с войском находятся у Утамыша, недалеко от этого селения расположились силы аварского правителя и акушинского кадия. Все они намереваются напасть у реки Инчхе на российские войска (Чекулаев, 2008, с. 124-125).

Как свидетельствуют источники, комендант Дербента А.Т. Юнгер неоднократно выполнял различного рода внешнеполитические поручения императорского правительства, направленные на укрепление власти России на территории Западного Прикаспия. Так, в 1722 г. правительство России рекомендовало А.Т. Юнгеру и наибу Имам-Кули-беку принять меры по обеспечению безопасности табасаранского правителя Рустема. Другой правитель Табасарана майсум Махмуд-бек был взят под покровительство российской военной администрации в Дербенте (Сотавов, 2002, с. 87).

Правительство России попыталось привлечь на российскую сторону правителя казикумухского ханства - Сурхай-хана. Выполняя это поручение, летом 1723 г. А.Т. Юнгер написал ему послание. Насколько оживленной оказалась переписка, свидетельствует так называемый «Журнал Дербентского коменданта Юнгера» (ЦГАРД, ф. 11, оп. 1, д. 1, л. 5-7, 12-15, 20, 24-27, 37-40). К сожалению, попытка окончилась неудачей. 
В 1724 г. Сурхай-хан отправил А.Т. Юнгеру письмо, в котором сообщал о своем примирении с комендантом Баку князем Барятинским, попытках арестовать Хаджи-Давуда и уведомлял о своем отказе от участия вместе с другими дагестанскими владетелями в походе на Гяндже, для разорения города (Курукин, 2010, с. 115-116).

Правительство дало указание А.Т. Юнгеру установить за действиями Сурхай-хана контроль, постоянно отправлять разведчиков с целью получения сведений о намерениях казикумухского правителя. В случае возникновения реальной угрозы вторжения Сурхай-хана в пределы российских владений на Кавказе дербентского коменданта обязали принимать меры противодействия, безотлагательно сообщая о них в Петербург (ЦГАРД, ф. 18, оп. 1, д. 79, л. 3-4).

Комендант А.Т. Юнгер регулярно отправлял из Дербента разведчиков в подконтрольные России дагестанские владения с целью получения сведений о намерениях и замыслах феодальных правителей (ЦГАРД, ф. 18, оп. 1, д. 84, л. 21). Для этого использовались главным образом местные жители и казаки (ЦГАРД, ф. 382, оп. 1, д. 29, л. 49). В результате их действий, в частности, стало известно, что кумыкский правитель Чопан-шамхал имеет тесные контакты с Крымским ханом и даже просит прислать войско для борьбы с российским присутствием в Дагестане. Сведения были переданы в Санкт-Петербург (ЦГАРД, ф. 18, оп. 1, д. 84, л. 35).

В обязанности российских разведчиков входило выявление недоброжелателей. При этом они часто рисковали собственной жизнью, нередко жители персидских провинций им угрожали («Чего ради ее императорскому величеству в верности пребываете и от россиян шпионами ходите, а ныне де и свой шах имеэтца, коему в верности пребывать надлежит»), а то и «побивали до смерти» (Магарамов, 2021).

В 1731 г. Петрос Сонцов через служителей Сурхай-хана Казикумухского раздобыл информацию о планах турецкого паши поддержать правителя в случае начала им войны с русскими. В резиденцию Сурхай-хана прибыл Сулейман-паша, доставил 10000 руб. и письмо, в котором говорилось о передаче тому «во владения городы Бака, Дербент и Кубинская земля, Низовая и Шебран». По донесению разведчика, Сурхай-хан готовил нападение на российско-турецкую пограничную территорию в Кубинской провинции и «нанимал людей и давал триста рублев, кто б кубинского наипа до смерти убил, или земли спаит» (Магарамов, 2021). Подобные донесения русских агентов и шпионов позволяли российской администрации заблаговременно предпринимать контрмеры.

«Журнал коменданта Юнгера» содержит огромную переписку коменданта Дербента А.Т. Юнгера с уцмием Кайтага, табасаранскими правителями, кумыцкими князьями и Тарковским шамхалом (ЦГАРД, ф. 11, оп. 1, д. 1, л. 1-5, 7, 11, 19-21, 31-40). Объемная корреспонденция коменданта и кабинет-секретаря 
А.В. Макарова показывает, что А.Т. Юнгер сумел разобраться во взаимоотношениях живших в Дербенте мусульман, армян и индийских купцов. Он своевременно принимал те решения, которые помогли установить межнациональный мир, избежать конфликтов (Бабич, 2005, с. 43).

Российское правительство не ошиблось в выборе, поставив А.Т. Юнгера на пост такого стратегически важного пункта на Западном побережье Каспийского моря. Комендант сумел стабилизировать обстановку в самом Дербенте и его окрестностях. В результате действий А.Т. Юнгера окрестные дагестанские владетели (уцмий Кайтага, табасаранские правители, кумыцкие князья) признали над собой власть Российского государства.

Имеющиеся в нашем распоряжении архивные документы свидетельствуют, что правительство возложило на коменданта обязанность реализовывать экономическую составляющую кавказской политики. Помимо прочего, в обязанность А.Т. Юнгеру вменялось снабжение российской промышленности природными богатствами Дагестана, а также изыскание источников пополнения государственной казны.

Правительство приказывало коменданту собирать пошлины с приезжающих в город иностранных и российских купцов. Император Петр I включение в состав Российской империи западного побережья Каспийского моря рассматривал как способ повышения доходов императорской казны за счет сбора пошлин с различного рода товаров.

Всеми делами местной таможни ведал капитан Дербентского пехотного полка. Его помощниками являлись офицеры пехотных полков Дербентского гарнизона. Комендант Дербента установил порядок, что тот или иной капитан управлял таможней Дербента с 1 сентября по 2 января, после чего ему на смену заступал другой капитан.

Российские военные взимали сборы с привозимых на продажу купцами различного рода товаров и изделий ремесленного производства.

Пошлины взымались и за пользование дербентскими лавками. Торговцы, приезжавшие в Дербент для продажи своих товаров, уплачивали за свой товар от 1 руб. 20 коп. до 2 руб. 40 коп. Больше 15 дней торговец в Дербенте не мог пользоваться торговой лавкой в караван - сарае. Таможенному сбору подлежал и не проданный торговцем в Дербенте его товар. Он насил название - «саламат пул», в размере 40 коп. с одного вьюка. В Махачкалинском архиве имеются таможенные книги Дербента, другие документы свидетельствуют, что местная таможня приносила большой доход в императорскую казну.

Таможенная книга Дербента сообщает следующие данные: в 1723 г. 235 руб. 75 коп.; в 1724 г. - 839 руб. 51 коп.; в 1725 г. - 1671 руб. 58 коп.; в 1726 г. 1010 руб. 4 коп.; в 1727 г. - 1657 руб. 2 коп.; в 1728 г. - 1167 руб. 28 коп.; в 1729 г. 754 руб. 63 коп.; в 1730 г. - 1541 руб. 85 коп., всего по данным местного архива таможня Дербента перечислила в доход Российской империи с 1722 по 1735 гг. - 707759 руб. 29 коп. (Чекулаев, 2002, с. 68; Лысцов, 1951, с. 215). 
В таможенной книге указывались следующие данные: 1) Имя и фамилия купца и наименование товара; 2) дата; 3) О взимании пошлины с привезенного товара. И естественно процитируем запись таможенной книги Дербента за ноябрь 1726 - февраль 1727 г.:

20 декабрь 1726 г. в Дербент прибыл индеец Тився и привез 9 тай шолку чистого и заплатил следующие пошлины: Во оных таях весу 205 батманов и рященской покупки пошлин з батмана по 36 копеек и пол истребуя оную ценою, итого 75 руб. 16 копеек 3/4; самсарей з батмана по 16 коп. и пол, итого 33 руб. 82 копеек и пол гущей - ста по 12 копеек пол итого 1 руб. 12 копеек и пол железа - 10 копеек; всего 110 рублев 21 копеек 3/4

20 декабря 1726 г. Дербент прибыл грузинской армянин Давыда Багдасерова шолку чистова 2 тай и заплатил следующие пошлины: Во оных таях весу 25 батманов рященской покупки пошлин з батмана по 36 копеек и 1/2 1/3 1/10 итого 9 руб. 16 копеек и 1/2 самсарей 3 батмана по 16 коп. и 1/2 итого 4 руб. 12 коп. 3/4] гущей с тай по 12 копеек и 1/2 итого 25 коп. железа 10 коп. всего 13 рублев 64 коп.

Январь 1727 г. Дербент прибыл рященской мухометанец Шафия Наширева 8 тай шолку чистова и заплатил следующие пошлины: Во оных таях весу 136 батманов рященской покупки пошлин з батмана по 36 копеек 1/2 1/3 1/10] итого 19 руб. 96 коп. 1/2 железа 10 коп. всего 48 руб. (ЦГАРД, ф. 18, оп. 1, д. 17, л. 1, 8, 12.)

Дербентский комендант увеличивал доходы императорской казны и за счет других источников. Например, средств кружечного двора ${ }^{1}$.

В торговле Дербента большое место играла продажа чихиря. С 23 сентября 1725 г. по 1 января 1727 г. в доход императорской казны было получено 9025 рублей 34 копейки. Помимо этого, продажа овощей и прочего произраставшего в так называемом «дворцовом хозяйстве» было другим источником доходов казны с Дербента. Так с 24 сентября по 1 января 1727 г. было выручено 31 руб. 8 коп (Лысцов, 1951, с. 207-208, 210, 213, 214, 216).

Петр I стремился использовать для нужд российского государства природные богатства Западного Прикаспия. Ему было хорошо известно, что в соседних с Астраханской губернией Персидских провинциях климатические условия позволяли выращивать различного рода плодовые деревья. Садоводство являлось одним из основных отраслей сельского хозяйства жителей Дербента. Один из участников Персидского похода так пишет по этому поводу, что «по обеим сторонам за Дербентом жители разводили виноградные и другие сады, дыни и арбузы около города везде в большом количестве». Ф.И. Соймонов указывал, что «сады Дербента были наполнены яблоками, грушами, сливами, персиками и прочим». И.Г. Гербер также отмечал особенность областей, которые «наибольше в высоких толстых дубах состоят» и в которых «родятся дикие яблоки, груши, орехи грецкие, айва, сливы и прочие

1 Питейного заведения. - Н.Ч. 
овощи; а особенно в лесах растет дикий виноград» (Лысцов, 1951, с. 34, 36-39; Магомедов, 1998, с. 108-109).

Осматривая фруктовые сады, император Всероссийский, нашел, что здешний виноград превосходен. Сожаление у Петра I вызвал тот факт, что жители не умеют делать хорошие вина. По приказу правителя в 1722 г. комендант А.Т. Юнгер организовал в Дербенте так называемое «Дворцовое хозяйство Его Императорского Величества». В этом «хозяйстве» выращивали виноград, из которого силами военных дербентского гарнизона под руководством мастеров изготовляли чихирь ${ }^{1}$. Помимо винограда в садах и огородах культивировали шафран, фрукты и овощи (Бабич, 2005, с. 39-40).

А.Т. Юнгер регулярно сообщал в правительство о том, как функционирует это «Дворцовое хозяйство Е.И.В.». Так, 19 апреля 1724 г. он писал кабинетсекретарю А.В. Макарову о «хозяйственной жизни Дербентского гарнизона», а 15 мая 1725 г. - об отправке из Дербента для нужд императорского двора чихиря и шафрана (РГАДА, ф. 9, оп. 4, д. 68, л. 1179-1181 об.; д. 74, л. 829-831).

Комендант А.Т. Юнгер в своих донесениях в Петербург именовал «садами и огородами Его Императорского Величества», были «отписаны от дербентских жителей на Его Императорское Величество». Причиной этого было то, что эти дербентцы были противниками утверждения России в Дагестане и в Дербенте, в частности. В этом «хозяйстве» произрастали как овощи, так и фрукты. В дальнейшем были проведены большие работы по расширению и улучшению хозяйственных угодий императорского двора.

Екатерина I исполнила намерение своего великого супруга и выписала из Венгрии майора Туркула, который привел местное виноделие в хорошее состояние, стал производить белое и красное вино неплохого качества. Венгру Туркулу по указанию А.Т. Юнгера поручили непосредственное руководство посадкой винограда, надзор за садами и виноделием в Дербенте. По майорскому чину ему был положен оклад 50 руб. 22 октября 1733 г. Туркул ушел в отставку, сдав должность поручику Дубровскому.

И.Г. Гербер говорил, что у венгерского виного мастера не получалось из дербентского винограда изготовить вино, такое какое выделывалось в Европе. Гербер И. предлагал императорскому правительству пригласить изза границы - иностранных винных мастеров, которые должны были улучшить качество местного вина. Слова И.Г. Гербера были реализованы на практике. Прибыли в Дербент и другие специалисты-виноградари, в частности, Иван Проха.

Работавшие в Дербенте при виноградных садах 23 солдата сверх жалованья получали по 1 руб. на человека. 30 октября 1732 г. в садах Дербента работало уже 2 капрала и 40 рядовых. В дагестанском пехотном полку было 2 солдата - специалиста по садоводству. Кроме того, военные власти нанимали для работы в «садах Его Императорского Величества» местных жителей.

1 Молодое некрепкое вино. - Н.Ч. 
Так, 15 декабря 1725 г. 4 человека за подрезание винограда получили 13 руб. 50 коп., 15 февраля 1726 г. на эти цели потрачено 1 руб. 25 коп., а 1 декабря 12 руб. Военные занимались осмотром виноградных вин и несли караул у винных погребов. Обер-офицеры производили освидетельствование вина. Лишь после этого оно шло на продажу. Известно, что от продажи вина урожая 1731 г. было получено 3000 рублей.

Военнослужащие гарнизона Дербента из произраставшего в городе и его окрестностях винограда производили вино, напоминавшее по своим параметрам местный чихирь, который так и стал называться чихирем ${ }^{1}$. Вино было красного цвета, жесткий и острый вкус, было весьма слабое и скоро портилось «ввиду недостатка сосудов, удобных для сбережения вина впрок» (Броневский, 1823, ч. 2, с. 285.). Не столь хорошее, как венгерское, оно оказалось лучше местного. Чихирь хорошего качества импортировалось в Россию, а плохого продавалось в Дербенте.

Труд российских военных по выращиванию местного винограда и производства из него чихиря было не напрасным. Так в 1723 г. в дворцовом хозяйстве было приготовлено около 60 бочек чихиря или около 2000 ведер. В апреле 1732 г. к дворцу Ее Императорского Величества было переслано более 25 бочек и 111 ведер вина. Отправлялось оно и во все русские гарнизоны Низового корпуса. Приказ 1726 г. о необходимости отправления комендантом Дербента вина для довольствия императорского двора (ЦГАРД, ф. 18, оп. 1, д. 133, л. 160; д. 138, л. 52), данный факт говорит о том, что местный виноград очень нравился в России.

Продавали вино (чихирь) сами военные. Она занимала большое значение в торговле и тем самым увеличивала поступления в государственную казну. По архивным данным от продажи вина урожая 1732 г. получено 3008 руб. 48 коп., что составляло 1 / з гарнизонной казны (ЦГАРД, ф. 18, оп. 1, д. 169, л. 16; д. 61, л. 38-39; д. 70, л. 11, 117-118; д. 78, л. 38, 41-42; д. 140, л. 20-21; д. 169, л. 1).

Под непосредственным руководством А.Т. Юнгера российский гарнизон занимался и выращиванием шафрана. Красящие вещества в Россию долгое время привозили из-за рубежа. Петр I стремился обеспечить мануфактурную промышленность отечественным сырьем.

Приморская территория Кавказа с древних времен являлась местом, где выращивали пряные культуры. Шафран являлся важной составляющей для производства тканей. Он широко применялся как краситель, как приправа к пище, в медицине - для изготовления пластырей и бинтов, используемых в дербентских госпиталях и лазаретах. Помимо огородного (культурного), в «уездах» Дербента широко был распространен и дикий шафран. К сожалению, кавказский шафран уступал по качеству лучшим образцам европейского, потому что шафран раньше срока с грядки и не соблюдали условия сушки шафрана. Петр I требовал от комендантов российских гарнизонов при

1 В Персии после выдавливания винограда сок мешали с водой, что лишало его крепости. 
выращивании шафрана соблюдать все необходимые мероприятия (Лысцов, 1951, с. 41).

Работы по выращиванию шафрана начались в 1723 г. Основой рабочей силой были донские казаки. Их работой руководили местные жители, которым платили по 50 коп. (ЦГАРД, ф. 18, оп. 1, д. 20, л. 4 об - 6). Площади под шафраном увеличили за счет близлежащих у Дербента земель. В 1724 г. В 1724 г. в дворцовом хозяйстве было выращено и доставлено в Астрахань шафрана 119 фунтов, а позднее этот объем увеличился. Императорские власти в реализации планов по использованию природных богатств Кавказа придавали дербентского шафрана большое внимание.

Итогом энергичных мероприятий российских властей в регионе стало повышение качества шафрана, увеличивали площади огородов, где выращивали шафран. Его стали регулярно поставлять в Россию и Персию, где он высоко ценился и находил выгодный сбыт (Лысцов, 1951, с. 40-41.).

В компетенцию дербентского коменданта также вменялись вопросы поиска в регионе других трав и кореньев для красильного дела. 7 сентября 1722 г. император указал выдать 100 руб. «армянину именем Карапету, которой родом из Диарбекира, за то, что показал он инвенцию из травы имянуемой чоган, делают паташ (а по их - калеа), которым можно выделывать и умягчать шолк и шерсть в дело фабрики». Петр I увез армянина с собой, а комендант получил указание отыскать эту траву. 15 ноября 1722 г. А.Т. Юнгер доносил в Кабинет, что отправленный в Баку из Дербента торговый человек Амет Аметев «травы воу и красок, и марены не нашел, только желтых кореньев нашел», и обещал продолжить поиски в провинции Гилян, считавшейся родиной шелководства. Генерал М.А. Матюшкин в письме А.В. Макарову от 16 февраля 1725 г., информируя о поисках шерсти в прикаспийских областях, необходимой для мануфактурного производства, одновременно указывал на то, что «тростей толстых в Гиляне не родитца, а родитца в Мизандроне (Мазандеране)». Купленные в Гиляне все семьдесят тростей он отправил к императорскому двору в Петербург (Магарамов, Магомедов, 2021, с. 136).

20 декабря 1726 г. императорское правительство России произвело полковника А.Т. Юнгера в бригадиры. В должности коменданта Дербента А.Т. Юнгер находился до июля 1730 г., после этого он занял пост обер-коменданта г. Астрахани (Бабич, 2005, с. 42). В начале 1740 г. А.Т. Юнгер подал челобитную об отставке от службы по болезни и 3 марта 1740 г. правительство удовлетворило его просьбу «с награждением пропитания» по смерть, поскольку «никаких поместий за собой не имеет» (там же, с. 46). Дальнейшая судьба, а тем более дата смерти Андрея Томасовича Юнгера неизвестна. 
Journal of Frontier Studies. 2022. No 1 | ISSN: 2500-0225

Empire in a Personal Dimension | https://doi.org/10.46539/jfs.v7i1.381

\section{Выводы}

Выходец из шотландцев Андрей Томасович Юнгер, как и многие его сослуживцы по Северной войне, по решению Петра I стал участником Персидского похода 1722 г. Попав в Дагестан, он был назначен на должность коменданта Дербента. А.Т. Юнгер сумел добиться утверждения российской власти на вверенной территории. В обязанности коменданта крепости входило не только управление военным гарнизоном, расквартированным в крепости, но и осуществление функции правителя Дербента, решающего проблемы гражданского населения крепости. Имеющиеся в нашем распоряжении источники свидетельствуют: в связи с тем, в руках коменданта Дербента была сосредоточена вся полнота, как гражданской, так и военной власти в регионе. А.Т. Юнгер по своей являлся главой российской военной администрации на подконтрольной ему территории Дагестана и тем самым комендант Дербента, как и прочие коменданты российских гарнизонов Низового корпуса непосредственно занимались осуществлением основных положений кавказской политики Российской империи в Дагестане.

Под руководством А.Т. Юнгера в Дербенте успешно осуществлялась экономическая политика Российской империи: пополнение доходов казны, использование природных ресурсов (воплотившееся в создание в Дербенте так называемого «Дворцового» хозяйства Е.И.В.). Проанализированные архивные документы свидетельствуют о том, что полковник А.Т. Юнгер, занимая должность коменданта Дербента, справлялся с возложенными на него обязанностями и стал для дагестанских горцев и их правителей достойным представителем правительства Российского государства.

\section{Благодарности}

Исследование выполнено при финансовой поддержке РФФИ в рамках научного проекта № 20-09-42023 «Петр Великий в исторической судьбе Кавказско-Каспийского региона».

\section{Список литературы}

Бабич, М. В. (2005). Андрей Юнгер или о предках Эраста Фандорина в эпоху Петра Великого и его преемников. В Петровское время в лищах. Эрмитаж.

Бобровский, П. О. (1892). История 13-го лейб-гренадерского Эриванского его величества полка за 250 лет, 1642 - 1891. В 5 частях. Типография В. С. Балашева.

Владимирский пехотный полк. (1994). В П. С. Грачев (Ред.), Военная энциклопедия (Т. 2). Военное издательство.

Курукин, И. В. (2010). Персидский поход Петра Великого. Низовой корпус на берегах Каспия (1722-1735 г2.). Квадрига; Объединённая редакция МВД России.

Лысцов, В. П. (1951). Персидский поход Петра I 1722-1723 г2. МГУ. 
Магарамов, Ш. А. (2021). Российская империя в Западном Прикаспии в 1722-1735 гг.: Опыт управления регионом. Электронный Научно-Образовательный Журнал История, 12(10). https://doi.org/10.18254/S207987840017048-1

Магарамов, Ш. А., \& Магомедов, Н. А. (2021). Комендант Дербента А.Т. Юнгер (1722-1730 гг.): Опыт управленческой практики. В Г. Г. Матишов (Ред.), Народы Кавказа в XVIII-XXI вв.: История, политика, культура. Материалы VIII Международного форума историковкавказоведов (2. Пятигорск, 14-15 октября 2021 г.). Издательство ЮНЦ РАН.

Магомедов, Н. А. (1998). Дербент и Дербентское владение в XVIII -первой половине XIX в. Институт истории, археологии и этнографии ДНЦ РАН.

Майкова, Т. С. (Ред.). (2004). Гистория Свейской войны (Поденная записка Петра Великого). Кругъ.

Рабинович, М. С. (1979). Офицерские сказки и послужные списки начала XVIII века. В Актовое источниковедение: Сборник статей (сс. 108-122). Наука.

Российский государственный архив военно-морского флота (РГАВМФ). (б. д.-а). Ф. 233. On. 1. Д. 211.

Российский государственный архив военно-морского флота (РГАВМФ). (б. д.-b). Ф. 233. On. 1. Д. 213.

Российский государственный архив древних актов (РГАДА). (б. д.-а). Ф. 9. Оп. 4. Д. 61.

Российский государственный архив древних актов (РГАДА). (б. д.-b). Ф. 9. Оп. 4. Д. 63.

Российский государственный архив древних актов (РГАДА). (б. д.-с). Ф. 9. Оп. 4. Д. 68.

Российский государственный архив древних актов (РГАДА). (б. д.-d). Ф. 9. Оп. 4. Д. 74.

Российский государственный архив древних актов (РГАДА). (б. д.-е). Ф. 20. Оп. 1/47. Д. 10.

Сотавов, Х. Н. (2002). Дагестан в кавказской политике России, Ирана и Турции в первой половине XVIII века [Диссертация на соискание ученой степени кандидата наук]. Дагестанский государственный университет.

Центральный государственный архив Республики Дагестан (ЦГАРД). (б. д.-а). Ф. 11. On. 1. Д. 1. Центральный государственный архив Республики Дагестан (ЦГАРД). (б. д.-b). Ф. 18. On. 1. Д. $2 a$. Центральный государственный архив Республики Дагестан (ЦГАРД). (б. д.-с). Ф. 18. On. 1. Д. 5. Центральный государственный архив Республики Дагестан (ЦГАРД). (б. д.-с). Ф. 18. On. 1. д. 70. Центральный государственный архив Республики Дагестан (ЦГАРД). (б. д.-с). Ф. 18. On.1. д. 78. Центральный государственный архив Республики Дагестан (ЦГАРД). (б. д.-d). Ф. 18. On. 1. Д. 79. Центральный государственный архив Республики Дагестан (ЦГАРД). (б. д.-е). Ф. 18. Ол. 1. Д. 84. Центральный государственный архив Республики Дагестан (ЦГАРД). (б. д.-с). Ф. 18. On. 1. д. 140. Центральный государственный архив Республики Дагестан (ЦГАРД). (б. д.-с). Ф. 18. Оп. 1. д. 169 Центральный государственный архив Республики Дагестан (ЦГАРД). (б. д.-f). Ф. 382. On. 1. Д. 29. Чекулаев, Н. С. (2002). Место и роль Низового Корпуса в экономической политике России в Дагестане. В Материалы региональной научно-практической конферениии «Молодежь и Наука Дагестана», проведенного 24-25 сентября 2002 г. (Тезисы докладов) (с. 68). б. и. 
Шеленговский, И. И. (1909). История 69-го пехотного рязанского полка. Люблин, Т. 1. 1700 - 1804 г2. б. и.

\section{References}

Vladimir Infantry Regiment. (1994). In P. S. Grachev (Ed.), Military Encyclopaedia (Vol. 2). Military publishing house. (In Russian).

Babich, M. V. (2005). Andrei Junger or about Erast Fandorin's ancestors in the era of Peter the Great and his successors. In The time of Peter the Great in faces. Hermitage. (In Russian).

Bobrowski, P. O. (1892). History of His Majesty's 13th Life-Grenadier Regiment of Erivan for 250 years, 1642 - 1891. In 5 parts. V. S. Balashev's printing house. (In Russian).

Central State Archive of the Republic of Dagestan (CSPAD). (n. d.-a). F. 11. In. 1. C. 1. (In Russian).

Central State Archive of the Republic of Dagestan (CSPAD). (n. d.-b). F. 18. In. 1. C. 2a. (In Russian).

Central State Archive of the Republic of Dagestan (CSPAD). (n. d.-c). F. 18. In. 1. C. 5. (In Russian).

Central State Archive of the Republic of Dagestan (CSPAD). (n. d.-d). F. 18. In. 1. C. 79. (In Russian).

Central State Archive of the Republic of Dagestan (CSPAD). (n. d.-e). F. 18. In. 1. C. 84. (In Russian).

Central State Archive of the Republic of Dagestan (CSPAD). (n. d.-f). F. 382. In. 1. C. 29. (In Russian).

Chekulaev, N. D. (2002). The place and role of the Grassroots Corps in Russian economic policy in Dagestan. In Proceedings of the Regional Scientific-Practical Conference "Youth and Science in Dagestan", 24-25 September 2002. (Abstracts of reports) (p. 68). n. p. (In Russian).

Chekulaev, N. D. (2008). Russian troops in Dagestan in the context of Russian Caucasian policy (17221735). DSC RAS. (In Russian).

Chekulaev, N. D. (2010). Palace economy in Derbent in the 18th century. History issues, 5, 154-159. (In Russian).

Kurukin, I. V. (2010). Peter the Great's Persian campaign. Lower Corps on the shores of the Caspian Sea (1722-1735). Quadriga; United Editorial Board of the Russian Ministry of Internal Affairs. (In Russian).

Lystsov, V. P. (1951). Peter the Great's Persian campaign 1722-1723. MSU. (In Russian).

Magaramov, Sh. A. (2021). The Russian Empire in the Western Caspian Region 1722-1735: Experience of Regional Governance. Electronic Journal of History, 12(10).

https://doi.org/10.18254/S207987840017048-1(In Russian).

Magaramov, Sh. A., \& Magomedov, N. A. (2021). Commandant of Derbent A.T. Junger (1722-1730): A managerial experience. In Г. Г. Матишов (E.d.), Peoples of the Caucasus in the 18th-21st centuries: History, Politics, Culture. Proceedings of the VIII International Forum of Historians of the Caucasus (Pyatigorsk, 14-15 October 2021). Published by the Southern Scientific Centre of the Russian Academy of Sciences. (In Russian).

Magomedov, N. A. (1998). Derbent and the Derbent Region in the 18th and the first half of the 19th centuries. Institute of History, Archaeology and Ethnography, DSC RAS. (In Russian).

Maykova, T. S. (Ed.). (2004). Histories of the Nordic War (Peter the Great's End of Days Note). Krug. (In Russian). 
Rabinowitz, M. C. (1979). Officers' tales and service records of the early 18th century. In Act Source Studies: A Collection of Articles (pp. 108-122). Nauka. (In Russian).

Russian State Archive of Ancient Documents (RSAAD). (n. d.-a). F. 9. In. 4. C. 61. (In Russian).

Russian State Archive of Ancient Documents (RSAAD). (n. d.-b). F. 9. In. 4. C. 63. (In Russian).

Russian State Archive of Ancient Documents (RSAAD). (n. d.-c). F. 9. In. 4. C. 68. (In Russian).

Russian State Archive of Ancient Documents (RSAAD). (n. d.-d). F. 9. In. 4. C. 74. (In Russian).

Russian State Archive of Ancient Documents (RSAAD). (n. d.-e). F. 20. In. 1/47. C. 10. (In Russian).

Russian State Navy Archive (RSNA). (n. d.-a). F. 233. In. 1. C. 211. (In Russian).

Russian State Navy Archive (RSNA). (n. d.-b). F. 233. In. 1. C. 213. (In Russian).

Shelengovsky, I. I. (1909). History of the 69th Ryazan Infantry Regiment. Lublin, Vol. 1. 1700 - 1804. n. p. (In Russian).

Sotavov, H. N. (2002). Dagestan in the Caucasian politics of Russia, Iran and Turkey in the first half of the 18th century [PhD dissertation]. Dagestan State University. (In Russian). 